\title{
Preconsolidation stress of gibbsitic and kaolinitic Oxisols under a multipractice conservationist coffee system
}

\section{Pressão de pré-consolidação de Latossolos gibbsítico e caulinítico sob sistema de multipraticas conservacionista no cultivo cafeeiro}

\author{
Carla Eloize Carducci ${ }^{1 *}$; Geraldo César de Oliveira ${ }^{2}$; Walmes Marques Zeviani3; \\ Henrique Aparecido Laureano4; Samara Martins Barbosa5; \\ Eduardo da Costa Severiano ${ }^{6}$; Nilton Curi²
}

\section{Highlights}

LMR predicted slight resistance to compaction in gibbsitic Acrustox soils.

The variation in gibbsite content affected the soil strength.

Multipractice conservationist management systems reduce soil compaction.

\begin{abstract}
Our goal was to analyze the impact of a multipractice soil conservationist system on coffee production in tropical soils (LATOSSOLO VERMELHO-AMARELO caulinítico/kaolinitic Haplustox and LATOSSOLO VERMELHO-gibbsítico/gibbsitic Acrustox) in Minas Gerais, Brazil. In the experimental area, the soil management involved a set of multiple conservationist practices during cultivation for more than 3.5 yrs. Soil samples were collected at 0-5, 10-15, and 20-25 cm depths at two positions: planting rows and between rows. The soil physical and mechanical properties were determined, with a focus mainly on the preconsolidation stress model (preconsolidation stress versus matric tension). For the purpose of analysis, a split-split plot experimental design was implemented. A linear mixed regression model (LMR) was fitted, and

1 Prof $^{a}$ Dra $^{a}$ School of Agricultural Sciences, Graduate Program in Agribusiness, Federal University of Grande Dourados, UFGD, Dourados, MS, Brazil. E-mail: carlacarducci@ufgd.edu.br

2 Prof. Dr., Department of Soil Science, Federal University of Lavras, UFLA, Lavras, MG, Brazil. E-mail: geraldooliveira@ dcs.ufla.br; niltcuri@dcs.ufla.br

${ }^{3}$ Prof. Dr., Department of Statistics, Campus III, Federal University of Paraná, UFPR, Curitiba, PR, Brazil. E-mail: walmes@ufpr.br

${ }^{4}$ Master's Degree Student, Graduate Program in Statistics, UFPR, Curitiba, PR, Brazil. E-mail: henriquelaureano@ outlook.com.br

${ }^{5}$ Post-doctoral Student, Department of Soils and Fertilizers, State University of São Paulo, UNESP, Jaboticabal, SP, Brazil. E-mail: samarambar2014@gmail.com

${ }^{6}$ Prof. Dr., Graduate Program in Agricultural Sciences-Agronomy, Federal Institute Goiano, Campus Rio Verde, IFgoiano, Rio Verde, GO, Brazil. E-mail: eduardo.severiano@ifgoiano.edu.br

* Author for correspondence
\end{abstract}

Received: Aug. 18, 2020 - Approved: Oct. 14, 2020 
Wald's test was performed $(P<0.05)$. An improvement of soil physical quality for both Oxisols was observed at the planting row position. The effects of multipractice soil management after $3.5 \mathrm{yrs}$ of cultivation in association with increased gibbsite content could promote new soil structure organization, as revealed by LMR, resulting in more resilient soils (between rows) and increasing the resistance to external pressures on gibbsitic Acrustox. Overall, the findings herein are in concordance with global trends towards conservationist practices that may alleviate soil compaction in agricultural systems to maintain environmental sustainability. Key words: Agricultural gypsum. Gibbsite. Kaolinite. Linear mixed regression model. Soil compaction.

\section{Resumo}

Nosso objetivo foi analisar o impacto de um sistema de manejo do solo com multi-práticas conservacionistas para o cultivo cafeeiro em solos tropicais (LATOSSOLO VERMELHO-AMARELO caulinítico/ kaolinitic Haplustox and LATOSSOLO VERMELHO gibbsítico/ gibbsitic Acrustox) em Minas Gerais, Brasil. Na área experimental, o manejo do solo incluiu um conjunto de multi-práticas conservacionistas por mais de 3,5 anos. Amostras de solo foram coletadas em 0-5; 10-15; e profundidades de 20 a $25 \mathrm{~cm}$ em duas posições: linha e entrelinha. As propriedades físicas e mecânicas do solo foram determinadas, concentrando-se principalmente na modelagem da compactação (estresse de pré-consolidação versus tensão matricial). Para fins de análise, foi considerado o delineamento experimental de parcelas subsubdivididas. Foi ajustado o modelo de regressão linear mista (RLM), bem como o teste $F$ de Wald $(P<0,05)$. Melhorias na qualidade física do solo em ambos os Latossolos foi observada na linha de plantio. Os efeitos do sistema de manejo multipráticas usado após 3,5 anos de cultivo associado ao maior conteúdo de gibbsita podem promover uma nova organização da estrutura do solo revelada pelo RLM, que resulta em solos mais resilientes (na entrelinha), melhorando a resistência às pressões externas aplicadas ao Latossolo gibbsítico. No geral, os resultados aqui apresentadas estão de acordo com as tendências globais em direção a práticas conservacionistas que podem aliviar a compactação do solo em sistemas agrícolas e manter a sustentabilidade ambiental.

Palavras-chave: Caulinita. Compactação do solo. Gesso agrícola. Gibbsita. Modelo de regressão linear mista.

\section{Introduction}

Considered the largest world agricultural frontier, the Brazilian savanna biome (known as Cerrado) (Tollefson, 2010), also has a great potential for coffee-growing, particularly due to the gentle relief and granular soil structure that favors the air-water dynamics balance, promoting the growth and the coffee production. This condition has been occurring in Minas Gerais State, Brazil, which has $70 \%$ of the area with arabica coffee nationwide, with production of more than 30.71 million coffee bags (Conab, 2020). According to Bernardes et al. (2012), 86\% of the coffee plantations in Minas Gerais are in tropical soils, as the Oxisols, which have outstanding physical properties, influenced by their mineralogy (Ajayi et al., 2009a,b; Vollant-Tuduri et al., 2005), which in association with organic carbon, result in strong granular structure and high friability (Zinn et al., 2007; Severiano et al., 2013). 
However, the most Oxisols are susceptible to compaction under machine traffic (Ajayi et al., 2009a,b; Severiano et al., 2013; Andrade et al., 2017; Guimarães Júnnyor et al., 2019; Ferreira et al., 2020), even with different proportions of oxide/kaolinite in the clay fraction (weathering soil). Meanwhile, when used conservation techniques to cultivated this soils, improvements in the soil physical quality can occur, due to the increases of aggregates stability (Severiano et al., 2013; Iori et al., 2013; Silva et al., 2016; Vollant-Tuduri et al., 2005).

In this way, more detailed studies of the relation between soil mineralogy (oxide/kaolinite) and mechanical behavior when subjected to a soil conservationist management system, are justified and have both scientific and practical demand. They can be described in detail if used a robust statistical tool, which captures data variability, considers fixed and random effect components, reduces errors and produces accurate estimates, as the theory about mixed linear regression model (Laird \&Ware, 1982). This fact is significant for agricultural sustainability since soil compaction is one of the most investigated elements in agricultural sciences due to its potential to impact negatively crop production and is a precursor of erosion processes (Götze et al., 2016; Guimarães Júnnyor et al., 2019; Ferreira et al., 2020).

Thereby, our hypothesis was: 1- Oxisols with different and striking mineralogy under the same soil conservationist management system have similar physical and mechanical behavior. 2 - Higher gibbsite content in Oxisols may increase mechanical strength. In this sense, we aimed to analyze the impact of a multi-practice conservationist management system on the preconsolidation stress in two tropical soils (kaolinitic Haplustox and gibbsític Acrustox) for coffee production in the state of Minas Gerais, Brazil.

\section{Material and Methods}

\section{Study area description}

The study was carried out in two Oxisols on a commercial coffee farm, established in a 52 ha area located at São Roque de Minas, Upper São Francisco physiographic region, in western Minas Gerais, Brazil. The climate of the region is Cwa type, according to Köppen classification, with an average annual rainfall of 1,344 mm, a well-defined dry season from May to September (Alvares et al., 2014) and short droughts in the rainy season.

The studied soils were described, sampled and classified according to Brazilian Soil Classification corresponds to LATOSSOLO VERMELHO-AMARELO DISTRÓFICO Tb caulinítico and LATOSSOLO VERMELHO DISTRÓFICO Tb gibbsítico (Santos et al., 2018). They corresponds in the US Soil Taxonomy (Soil Survey Staff, 2014), with adaptations, as kaolinitic Haplustox $(\mathrm{KH})$ and gibbsitic Acrustox (GA), and Ferralsols in the Soil World Reference Base (IUSS Working Group WRB, 2014). The kaolinitic Haplustox is situated at the summit of landscape, coordinates $20^{\circ} 15^{\prime} 43^{\prime \prime} \mathrm{S}$ and $46^{\circ}$ $22^{\prime} 17 " \mathrm{E}$, altitude of $876 \mathrm{~m}$; and the gibbsitic Acrustox is situated in the middle of the hillside, coordinates $20^{\circ} 11^{\prime} 35^{\prime \prime} \mathrm{S}$ and $46^{\circ} 22^{\prime} 07^{\prime \prime} \mathrm{E}$, altitude of $841 \mathrm{~m}$. 


\section{Commercial coffee crop description}

The commercial coffee cultivation was implemented in both Oxisols, according to a distinctive multi-practice conservationist management system including:

A) soil amendment, for fertility purposes, by the incorporation of $4 \mathrm{Mg} \mathrm{ha}^{-1}$ of dolomitic limestone and $1.92 \mathrm{Mg} \mathrm{ha}^{-1}$ of gypsum in the total area, and $8 \mathrm{Mg} \mathrm{ha}^{-1}$ of dolomitic limestone $\left(2 \mathrm{~kg} \mathrm{~m}^{-1}\right)$ and NPK fertilizer (08-44-00), enriched with $1.5 \% \mathrm{Zn}$ and $0.5 \% \mathrm{~B}$, in the planted furrow. B) An additional surface application of gypsum $\left(7 \mathrm{~kg} \mathrm{~m}^{-1}\right)$, three months after planting, was performed in the planting row and covered, at the base of the coffee stem, with an interrow mixture of soil and plant material in the form of a $0.50 \mathrm{~m}$ ridge (Silva et al., 2015; Carducci et al., 2015). C) planting and maintenance of Brachiaria decumbens (Syn. Urochloa decumbens) as a tropical forage, in the interrow that was periodically cutting using a brush cutter. D) furrows at $0.60 \mathrm{~m}$ of depth for the crop plantation and formation of small ridges with a height of $0.50 \mathrm{~m}$ next to the coffee stem after amendment applications; E) crop operations were carried out using animal traction equipment and the harvest was performed mechanically.

These practices as a whole can contribute to denser and deeper coffee radicular systems can develop, enhancing the development of the aboveground parts and reproductive buds (Carducci et al., 2015; Silva et al., 2016b; Barbosa et al., 2020). Furthermore, it has been shown this type of multi-practice conservationist system allows coffee plants to endure water stress and could increase the soil water recharge (Santos et al., 2014; Silva et al., 2015; Silva et al., 2019).
Soil sampling and physical analyses

We sampled the two Oxisols: (kaolinitic Haplustox (KH) and gibbsitic Acrustox (GA)) when the coffee crop was 3.5 yr-old of cultivation. Three random trenches having dimensions of $0.30 \times 0.30 \times 0.40 \mathrm{~m}$ were dug along to the planting rows for each soil, which means three field repetitions. All samples were collected in two sampling positions: planting row right below the additional gypsum application and in the interrow at $0-5 ; 10-$ 15; and $20-25 \mathrm{~cm}$ depths, these layers were selected for recording the entire history of applied external stresses (Guimarães Júnnyor et al., 2019; Keller et al., 2014; Dias Júnior \& Pierce, 1995).

Undisturbedsoilsampleswerecollected using volumetric rings $(6.5 \mathrm{~cm}$ diameter and $2.5 \mathrm{~cm}$ height) covered with a plastic film and paraffin for preservation until the physical and mechanical analyses were carried out. These samples were used to determine the physical properties as: soil bulk density (BD), total soil porosity (TP), macroporosity (MA), microporosity (MI). Disturbed soil samples were collected for determination of particle size analysis by the pipette procedure (Day, 1965; Teixeira et al., 2017).

The soil samples were saturated with a gradually rising water elevation for $48 \mathrm{~h}$, posteriorly were subjected to matric tensions $\left(\Psi_{m}\right)$ of: $1,2,4,6$, and $10 \mathrm{kPa}$ in suction units, as well as $33,100,500$, and $1500 \mathrm{kPa}$ in porous plate chambers (Genuchten, 1980). For tensions above $1500 \mathrm{kPa}$ the WP4-T psychrometer was used (Carducci et al., 2013). After the equilibrium of the samples at the predetermined $\Psi_{m^{\prime}}$ was performed the penetration resistance, using a penetrograph model MA 93, with constant speed $(10 \mathrm{~cm}$ 
$\left.\min ^{-1}\right)$, straight circular cone $\left(45^{\circ}\right)$ and radius of $1.92 \mathrm{~mm}$ (Silva et al., 2015; Peixoto et al. 2019). After this procedure all the samples were weighed and then oven-dried at 105$110^{\circ} \mathrm{C}$ for $48 \mathrm{~h}$ to determine the water content corresponding to $\Psi_{\mathrm{m}}$ (Genuchten, 1980), totaling 36 samples.

The macroporosity was calculated by the difference between total porosity [TP $=1$ - (BD/PD)] and microporosity (water retained at $6 \mathrm{kPa}$, this is the limit between macro and micropores by capillarity methods), according to Danielson and Sutherland (1986), in which particle density (PD) determined by the volumetric flask procedure (Blake \& Hartge, 1986).

Uniaxial compression tests to estimate soil compaction

Another set of soil undisturbed samples was tested to uniaxial compression (Dias Júnior \& Pierce, 1995; Ajayi et al., 2009a,b; lori et al., 2013). Initially the samples were saturated by capillarity and equilibrated at the following matric tensions $\left(\Psi_{\mathrm{m}}\right): 6,33$, 100, 1500, and $3000 \mathrm{kPa}$, in three field's repetitions. These matric tensions range cover from the friability zone until the residual water content that is still able to regulate microbial biochemical processes and influence the desiccation tolerance of germinated seeds and seedlings when subjected to high matric tension $\left(\Psi_{\mathrm{m}}>1500 \mathrm{kPa}\right)$, besides acting as an aggregation lubricant agent (Severiano et al., 2013; Carducci et al., 2013).

After the equilibrium in the predetermined $\Psi_{m}$ the samples were submitted to uniaxial compression tests, and for that a pneumatic S-450 Terraload floating ring consolidometer (Durham Geo Enterprises, Stone Mountain, GA, USA) was utilized. The samples were kept in the compression chamber and subjected to pressures of 25, 50, 100, 200, 400, 800, and $1600 \mathrm{kPa}$. Each pressure was applied until $90 \%$ of the maximum deformation was reached (Taylor, 1948; Dias Júnior \& Pierce, 1995). Subsequently, the pressure was increased to the next level without releasing the one previously applied, starting in the lowest pressure and proceeding to the highest pressure. Using an extension meter device, the soil deformation as a function of the applied load was monitored by displacement and it was further converted into a density increase.

After this test, the samples were ovendried at $105-110^{\circ} \mathrm{C}$ for $48 \mathrm{~h}$ to determine the dry mass. We used 180 samples for this test. The pressures applied in this test simulate the static pressure applied by different agricultural and forestry machinery (Eliasson, 2005; Horn et al., 2007; Keller et al., 2014; Pirnazarov \& Sellgren, 2015).

A soil compression curve of each sample was obtained by plotting the logarithm (base 10) of the applied pressure on 5 the $x$-axis $v$. The soil deformation on the $y$-axis. The preconsolidation stress ( $\sigma p)$ were determined according to the method described by Dias Júnior and Pierce (1995) for estimating the intersection of the two regression lines obtained for the first two points (when $\Psi_{\mathrm{m}}$ $\leq 100 \mathrm{kPa}$ ) or four points (when $\Psi_{\mathrm{m}} \geq 100$ $\mathrm{kPa}$ ) of the applied stress sequence in the secondary compression portion of the compression curve. The extension of the virgin compression line was determined from the points associated with an applied stress of 800 and $1600 \mathrm{kPa}$. These values were adjusted as a function of the matric tension ( $\Psi \mathrm{m})$ to obtain the preconsolidation pressure curve. 
Chemical and mineralogical analyses of Oxisols

Chemical characterization included $\mathrm{SiO}_{2}, \mathrm{Al}_{2} \mathrm{O}_{3}$ and $\mathrm{Fe}_{2} \mathrm{O}_{3^{\prime}}$ determined by sulfuric acid digestion. This method is a standard procedure for the analysis of Brazilian soils and indicative of weathering degrees by the computation of the ratios $\mathrm{SiO}_{2} / \mathrm{Al}_{2} \mathrm{O}_{3}$ and $\mathrm{SiO} 2 /$ (Al2O3 + Fe2O3). The hematite and goethite contents were derived from X-ray diffraction measurements and stoichiometric ratios, as well as the relationship between gibbsite and kaolinite $[\mathrm{Gb} /(\mathrm{Gb}+\mathrm{Kt})]$, being the aluminum contents of the kaolinite derived from its ideal chemical formulae, as well as the hematite and goethite ratio $[\mathrm{Hm} /(\mathrm{Hm}+\mathrm{Gt})]$, according to Resende, Bahia Filho, and Braga (1987).

\section{Statistical analyses}

Experimental design to soil physical attributes

Linear mixed effects model were used to model the responses: soil bulk density (BD), total porosity (TP), macro and microporosity as function of experimental factors: soil, position and depth (Laird \& Ware, 1982). The statistical model assumes a split split plot experimental design:

$$
\begin{gathered}
\begin{array}{c}
\text { yikjl }=\mu \\
+S_{i}+P_{j}+D_{k}+(S P)_{i j}+(S D)_{i k}+(P D)_{j k} \\
+(S P D)_{i j k}+e i l+e i j l+e i j k l
\end{array} \\
\text { eil } \sim \operatorname{Normal}(0, \sigma 2 a)[6 \text { whole plots] } \\
\text { eijl } \sim \operatorname{Normal}(0, \sigma 2 b) \text { [12 subplots] } \\
\text { eijkl Normal }(0, \sigma 2)[36 \text { data points] }
\end{gathered}
$$

Where: yijkl: is response observed at the experimental condition $i j k l ; \mu$ : is a constant that belongs to all observations; $S i$ is the effect of soil $i=1,2 ; P j$ is the effect of position $j=1,2$;
Dk is the effect of depth $k=1,2,3$; eil is the experimental error at experimental unit il, eijl is the experimental error at experimental unit $i j l$ and eijkl is the experimental error at sample unit ijkl. The following terms are two and three way interactions among soil taxon, position and depth. This model was estimated by restricted maximum likelihood (REML). The Akaike (AIC) and Bayesian criteria (BIC) test was used to compare the models fitted.

\section{Experimental design to penetration resistance}

To evaluate the soil penetration resistance we used the linear mixed effects model as function of experimental factors: soil, position and matric tension. As suggested by exploratory data analysis, the effect of matric tension (at log 10 scale) on penetration resistance can be properly described by a second order degree polynomial in the range of tension from 6 to $1500 \mathrm{kPa}$. The statistical model is:

$$
\begin{gathered}
\text { yijkl }=\mu+S_{i}+P_{j}+\beta_{1} T_{k}+\beta_{2} T_{2 k}+(S P)_{i j}+\left(\beta_{1 i} T_{k}+\beta_{2 i} T_{2 k}\right)+ \\
\left(\beta_{1 j} T_{k}+\beta_{2 j} T_{2 k}\right)+\left(\beta_{1 i j} T_{k}+\beta_{2 i j} T_{2 k}\right)+e i l+e i j l+e i j k l \\
\text { eil } \sim \operatorname{Normal}(0, \sigma 2 a)[6 \text { whole plots] } \\
\text { eijl } \sim \operatorname{Normal}(0, \sigma 2 b) \text { [12 subplots] } \\
\text { eijkl } \sim \operatorname{Normal}(0, \sigma 2)[48 \text { data points] }
\end{gathered}
$$

Where: yijkl: is response observed at the experimental condition $i j k$; $\mu$ : is a constant that belongs to all observations; $\mathrm{Si}$ is the effect of soil $i=1,2 ; P j$ is the effect of position $j=1,2 ; \quad \beta 1$ and $\beta 2$ : are the first and second order effect of log 10 matric tension; eil is the experimental error at experimental unit il, eijl is the experimental error at experimental unit ijl and eijkl is the experimental error at sample unit ijkl. The following terms are two and three 
way interactions among soil, position and matric tension. This model was estimated by restricted maximum likelihood (REML).

The AIC and BIC test was used to compare the models fitted. Subsequently confidential intervals were constructed for the set of replications, in order to compare the data variability. So it can be stated that $95 \%$ of the samples were predicted.

Experimental design to preconsolidation stress model

Based on exploratory data analysis, the effect of log of matric tension $\left(\Psi_{\mathrm{m}}\right)$ on log of preconsolidation stress $\left(\sigma_{p}\right)$ (response variable) can be properly described by a second order polynomial in each experimental condition (combination of soil taxon, sampling position and depth levels). Therefore, log of preconsolidation stress was modelled as a function of soil taxon, sampling position, depth and log of matric tension. All interactions (until those of 4 th way) were included in the model.

The effect of different sizes experimental units was accounted by random effects terms at intercept level. Likelihood ratio tests were performed to check the relevance random effects terms and Wald $F$ tests were performed check the relevance of fixed effect terms, so those not relevant terms were dropped getting a simple model (Laird \& Ware, 1982). The complete model is:

$$
\begin{gathered}
\text { yijklm }=\mu+S_{i}+P_{j}+D_{k}+\left(\beta_{1} T_{1}+\beta_{2} T_{2}\right) \\
+(S P)_{i j}+\cdots+(S P D) i j k+\cdots+\left(\beta_{1 i j k} T_{1}+\beta_{2 i j k} T_{2}\right) \\
+ \text { eim+eijm }+ \text { eijkm+eijklm } \\
\text { eim } \sim \operatorname{Normal}(0, \sigma 2 a)[6 \text { whole plots] } \\
\text { eijm } \sim \operatorname{Normal}(0, \sigma 2 b)[12 \text { subplots }]
\end{gathered}
$$

eijkm Normal $(0, \sigma 2 c)$ [36 sub-sub subplots]

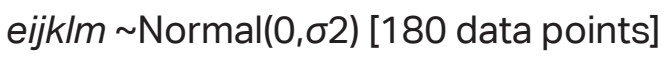

Where: yijklm is the response at the ijklm experimental condition; $\mu$ : is a constant that belongs to all experimental condition; $\mathrm{Si}$ : accounts for the soil effect; $P$ : accounts for the sampling position effect; $D k$ : accounts for the soil depth effect; $\beta 1$ and $\beta 2$ : accounts for the linear in quadratic effect of matric tension; eim accounts for the experimental error at whole plots, eijm at sub plots, eijlm at sub sub plots and eijk/m at data point level.

All two and three way interaction of the above terms is included. This model was fitted by restricted maximum likelihood (REML). Non relevant terms were dropped to get a simpler model to inspect the research hypothesis.

After this step, we estimated curve coefficients for each experimental point resulted of combining soil, position and depth levels ( 12 equations at all). These fitted curves have the following equation:

$$
y=\beta_{0}+\beta_{1} x+\beta_{2} x^{2}
$$

Where: $y$ is the conditional mean of log 10 to preconsolidation stress, $x$ is the log 10 of matric tension and $\beta 0, \beta 1$ and $\beta 2$ are intercept, slope and curvature parameters of the second order polynomial.

Wald $\mathrm{F}$ test were applied to test with two curves are equal. The null hypothesis states that all three curve parameters $(\beta 0, \beta 1$, $\beta 2$ ) are simultaneous equal for a pair of curves $a$ and $b$.

$$
\begin{aligned}
& \beta_{0 a} \beta_{0 b} \\
\mathrm{H}_{0}: & \beta_{1 a}=\beta_{1 b} \\
\beta_{2 a} & \beta_{2 b}
\end{aligned}
$$


Curves from soils were compared for each position and depth combination (6 conditions). The F statistic is the same for all depth at the same position to compare soils, is important to note that soil and depth had only additive effect. The same test was applied to test equality of curves between position for each soil and depth combination (6 conditions). The F statistic is the same for all depth at the same soil to compare positions because position and depth had only additive effect. All statistical analysis was performed by $\mathrm{R}$ lenguage (R core Team, 2019).

\section{Table 1}

Particle size distribution, chemical and mineralogical characterization of kaolinitic Haplustox (KH) and gibbsitic Acrustox (GA) at Bw horizon ( $\geq 1.00 \mathrm{~m}$ of depth)

\begin{tabular}{|c|c|c|c|}
\hline & & $\mathrm{KH}$ & GA \\
\hline Clay & \multirow{3}{*}{$\mathrm{g} \mathrm{kg}^{-1}$} & 724 & 895 \\
\hline Silt & & 213 & 46 \\
\hline Sand & & 63 & 59 \\
\hline $\mathrm{SiO}_{2}$ & \multirow{3}{*}{$\mathrm{g} \mathrm{kg}^{-1}$} & 243.3 & 127.2 \\
\hline $\mathrm{Al}_{2} \mathrm{O}_{3}$ & & 285.3 & 364.1 \\
\hline $\mathrm{Fe}_{2} \mathrm{O}_{3}$ & & 122.1 & 158.2 \\
\hline $\mathrm{Kt}^{(1)}$ & \multirow{4}{*}{$\%$} & 52.30 & 27.34 \\
\hline $\mathrm{Gb}$ & & 40.46 & 54.02 \\
\hline $\mathrm{Hm}$ & & 0.69 & 11.92 \\
\hline Gt & & 6.55 & 6.72 \\
\hline $\mathrm{Ki}$ & & 1.45 & 0.59 \\
\hline $\mathrm{Kr}$ & & 1.14 & 0.46 \\
\hline $\mathrm{Hm} /(\mathrm{Hm}+\mathrm{Gt})$ & & 0.10 & 0.63 \\
\hline $\mathrm{Gb} /(\mathrm{Gb}+\mathrm{Kt})$ & & 0.44 & 0.66 \\
\hline $\mathrm{SiO}_{2} / \mathrm{Al}_{2} \mathrm{O}_{3}$ & & 1.45 & 0.59 \\
\hline $\mathrm{SiO}_{2} /\left(\mathrm{Al}_{2} \mathrm{O}_{3}+\mathrm{Fe}_{2} \mathrm{O}_{3}\right)$ & & 1.14 & 0.46 \\
\hline
\end{tabular}

(1) Kt: kaolinite, Gb: gibbsite, $\mathrm{Hm}$ : hematite, Gt: goethite. Ki: molecular ratio $\mathrm{SiO}_{2}: \mathrm{Al}_{2} \mathrm{O}_{3} ;{ }^{2}: \mathrm{Kr}$ : molecular ratio $\mathrm{SiO}_{2}:\left(\mathrm{Al}_{2} \mathrm{O}_{3}+\right.$ $\mathrm{Fe}_{2} \mathrm{O}_{3}$ ) by Resende, Bahia Fialho and Braga (1987) and Pedrotti et al. (2003). 


\section{Results}

Physical and mineralogical attributes of Oxisols

The Oxisols evaluated in this study as the kaolinitic Haplustox $(\mathrm{KH})$ showed the intermediate ratio of gibbiste/kaolinite [Gb/ (Gb+Kt): 0.44] and gibbsite content (40.5\%) (Pedrotti et al., 2003; Resende, Bahia Filho, \& Braga 1987) relatively closer to gibbsitic Acrustox (GA: $54.02 \%$ and $\mathrm{G}$ ) although $\mathrm{GA}$ is more weathered than $\mathrm{KH}$ (Ki: 0.59; Kr:0.46; Gb/ $(\mathrm{Gb}+\mathrm{Kt}): 0.66)$ (Table 1).

According to the exploration of the physical attributes data, there was a significant difference for the soil bulk density (BD), between the Oxisols $(P<0.05)$ and between the depths only for the $\mathrm{GA}\left(0.92-1.00 \mathrm{~g} \mathrm{~cm}^{-3}\right)$. With relation to the pores distribution, there was a significant difference for the total porosity (TP) between the soils and the macroporosity $(\mathrm{MA})$ between the sampling positions $(P<0.05)$ with the highest values being observed in the planting row for both soils (Figure 1). Regarding soil penetration resistance (PR), there were not differences for positions between and inside soils, with increasing values according to the soil matric tension increment as the overlapping confidential intervals (Figure 2).
Preconsolidation stress for diagnosing the compaction of Oxisols

Linear mixed regression model was proposed to more accurately describe the preconsolidation stress model [preconsolidation stress $\left(\sigma_{\mathrm{p}}\right)$ versus matric tension $\left(\Psi_{m}\right)$ ] (Figure 3 ). In this model, the random effect allows the curves have different intercepts and slopes to account for the variability among experimental units.

From this model, by Wald F tests, there were not $4^{\text {th }}$ degree (soil taxon, sampling position, depth and matric tension) significant interactions neither $3^{\text {rd }}$ degree (soil taxon, sampling position and depth). All two way interactions were kept except those involving depth and soil or depth and position. So, depth and soil had only additive effect, the same occurred for depth and position, that means, the preconsolidation stress model at different depths were not significant between the sampling positions - row and interrow in the same Oxisol. Nevertheless, they were significantly different between soils (Figure 3).

When we analyzed all models $\left(\sigma_{\mathrm{p}} \times \Psi_{\mathrm{m}}\right)$ (Figure 3 ) the confidence bands overlapping at all depths. In the planting row indicating that these soils present the same strength to the external load application. The opposite is observed in the interrow position, where the GA presented higher pre-consolidation stress values (100-300 $\mathrm{kPa}$ ), especially in the range of higher plant water availability (Figure 2 and 3). 

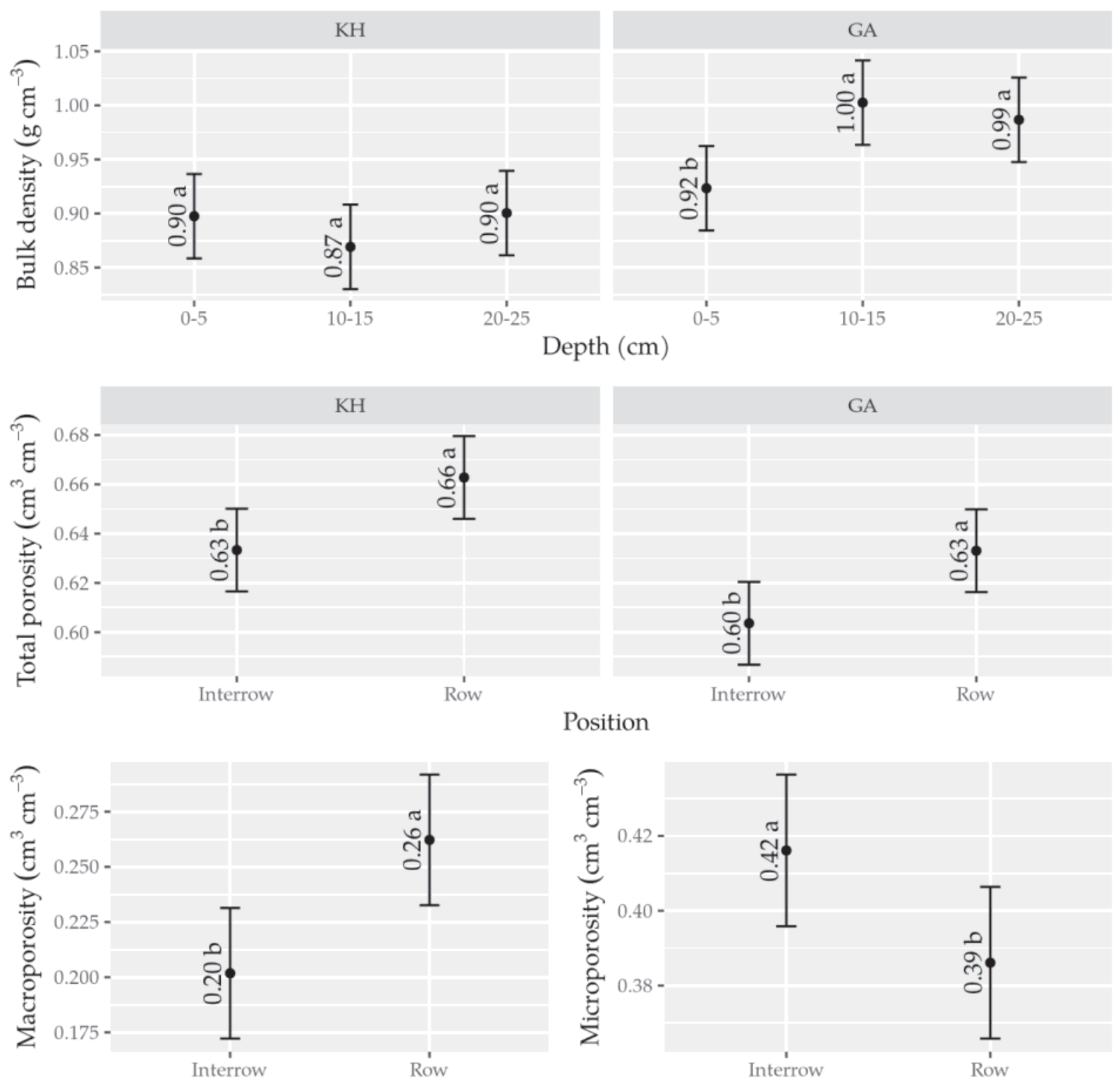

Position
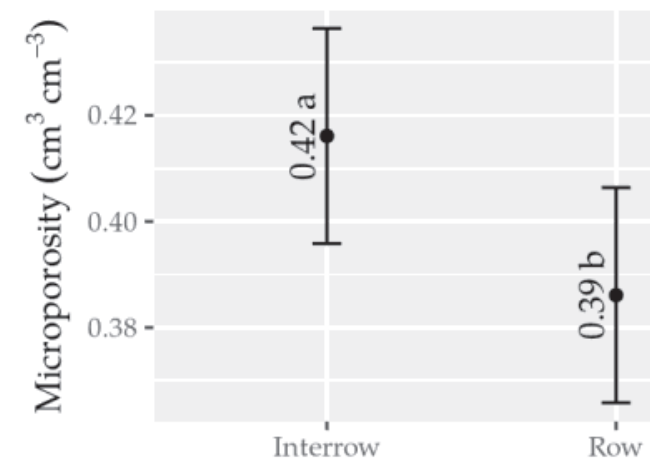

Position

Figure 1. Soil bulk density (BD - $\left.\mathrm{g} \mathrm{cm}^{-3}\right)$, total porosity (TP), macro (MA) and microporosity (MI) $\left(\mathrm{cm}^{3} \mathrm{~cm}^{-3}\right)$, at the $0-5,10-15$ and $20-25 \mathrm{~cm}$ depths and two sample position: row and interrrow, respectively for kaolinitic Hapustox $(\mathrm{KH})$ and gibbsitic Acrustox $(\mathrm{GA})$ under same multi-practice management system. The bars represent a confidence interval (0.95). Comparison test was performed as Akaike (AIC) and Bayesian criteria (BIC). 

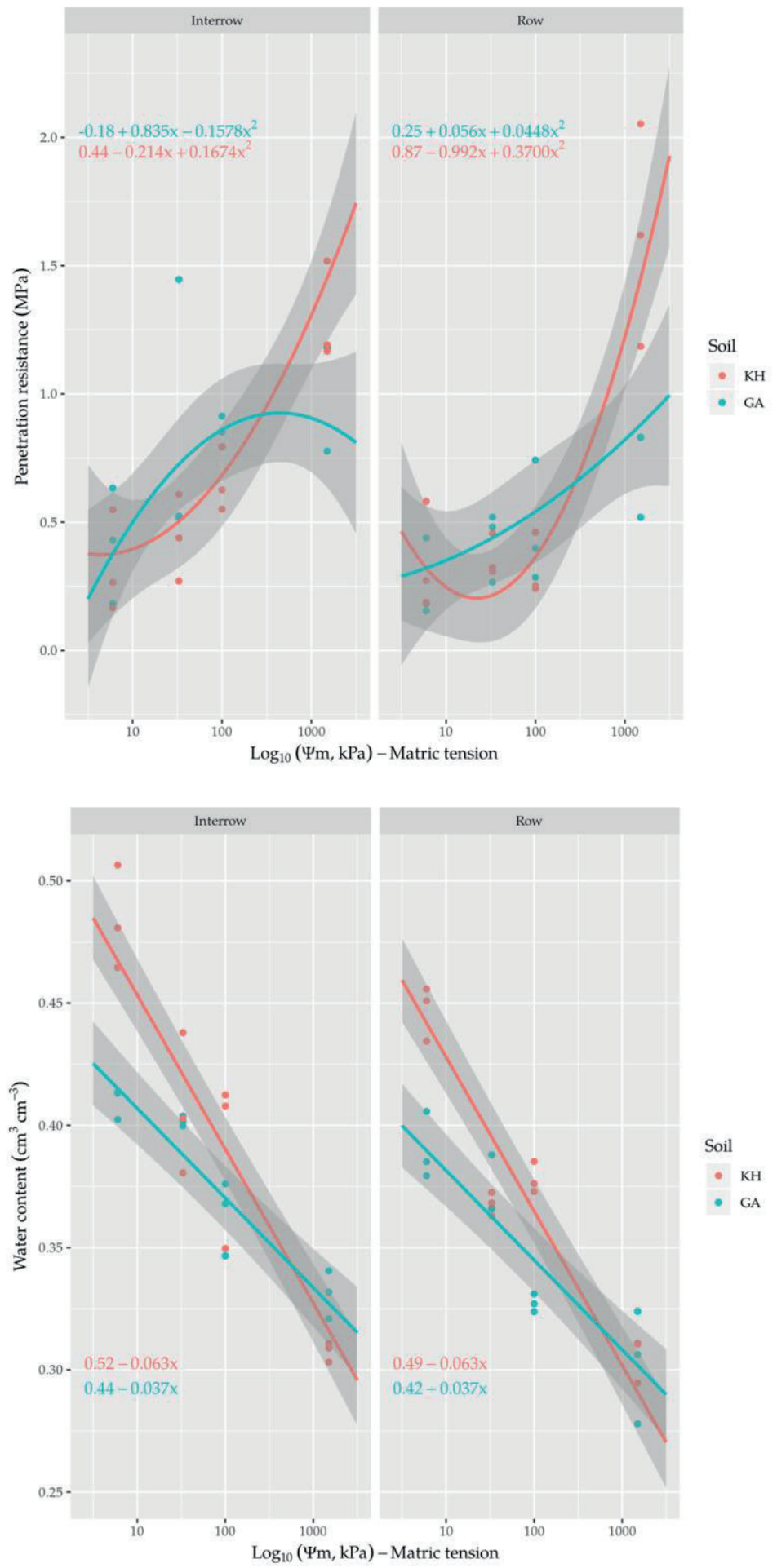

Soil

Figure 2. Penetration resistance at different water tensions $(6,33,100,1500$, and $3000 \mathrm{kPa})$ for kaolinitic Hapustox (KH) and gibbsitic Acrustox (GA) in two sample positions: row and interrrow, under same multi-practice management system. The bands represent a confidence interval (0.95). Comparison test was performed as Akaike (AIC) and Bayesian criteria (BIC). 

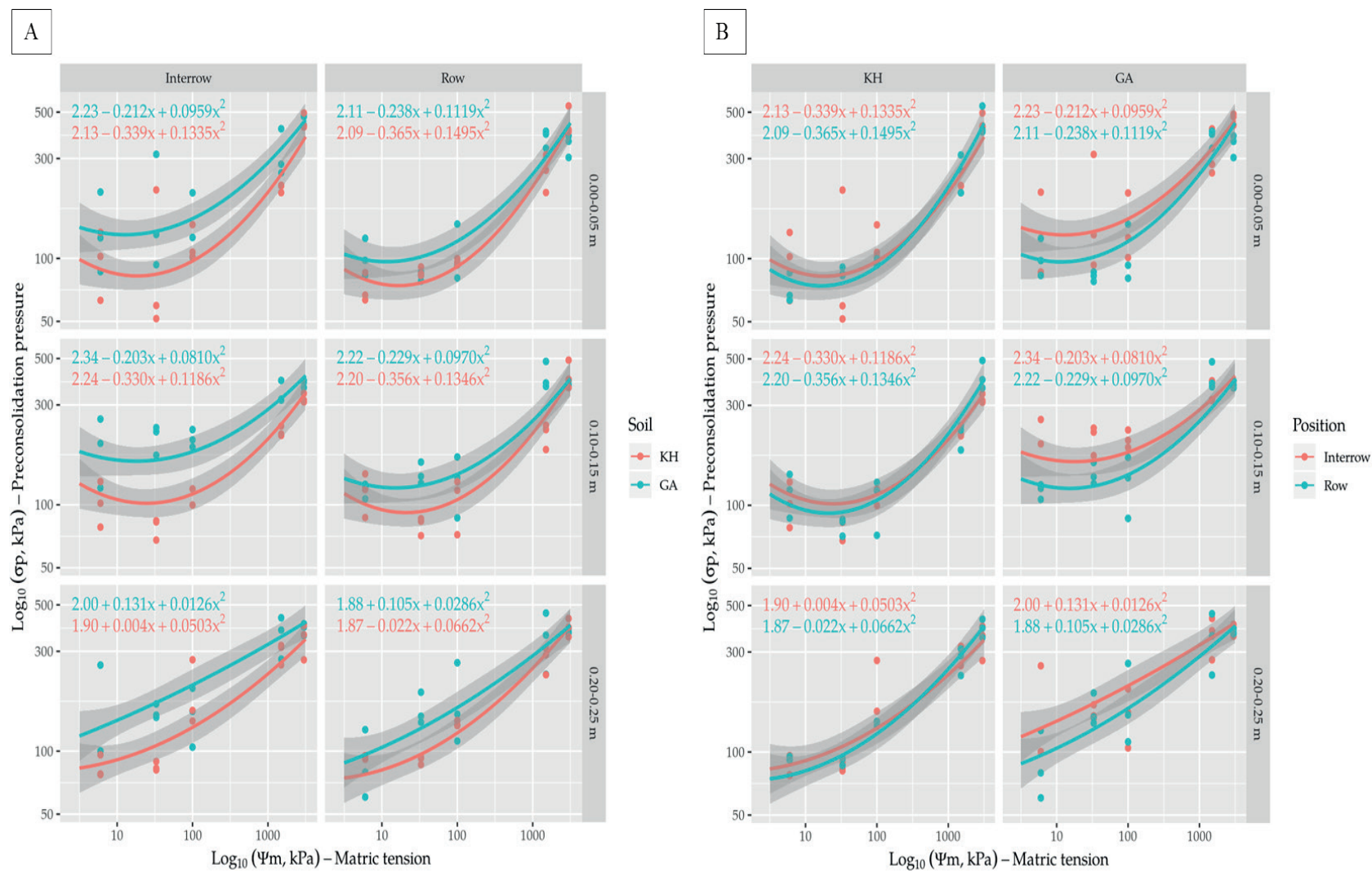

Figure 3. Preconsolidation stress model (preconsolidation stress $\left(\sigma_{\mathrm{p}}\right)$ versus matric tension $\left(\Psi_{\mathrm{m}}\right)$ at the $0-5,10-15$ and $20-25 \mathrm{~cm}$ depths and two sampling position: row and interrow for each soil: kaolinitic Haplustox (KH) and gibbsitic Acrustox (GA), under same multi-practice management system. The confidence bands have $95 \%$ of coverage probability for the mean. A) Between soils, B) Between position.

\section{Discussion}

The intermediate gibbsite ratio (Pedrotti et al., 2003; Resende, Bahia Filho, \& Braga, 1987) associated with the multipractice management system studied can be correspond to a new formation of an intermediate structure between granules and blocks (blocky-granular structure) with great stability in kaolinitic Haplustox $(\mathrm{KH})$, which to our knowledge has not yet been explored in the scientific literature previously (Vollant-Tuduri et al., 2005; Ajayi et al., 2009; Ajayi et al., 2010; Severiano et al., 2013; An et al., 2015; Bonetti et al., 2017).
Moreover, both Oxisols were on the same multi-practice management system presented many similarities in relation to the physical attributes, especially in the planting row, on account of the soil mixing when the coffee crop was planted in 3.5-yrs ago, and to the contribution of coffee plants and tropical forage - Brachiaria (periodically cut and added in the row) residues.

In previous studies involving Oxisols with kaolinitic mineralogy as the $\mathrm{KH}$, low macroporosity, higher bulk density and mechanical resistance were found due to the blocky structure which was associated to 
the face-to-face arrangement of the kaolinite plates. However, the Oxisols with gibbsitic mineralogy, such as gibbsitic Acrustox (GA), presented higher porosity and lesser bulk density values, due to its granular, wellrounded and highly stable structure (VollantTuduri et al., 2005; Ajayi et al., 2009b, Ajayi et al., 2010; Severiano et al., 2013; Skorupa et al., 2016; Pedrotti et al., 2003).

However, the values found even at the maximum $\Psi_{\mathrm{m}}: 3000 \mathrm{kPa}, \theta: \pm 0.20 \mathrm{~cm}^{3} \mathrm{~cm}^{-3}$, PR: 1.7 MPa are related to less than $2.5 \mathrm{MPa}$ values for PR (Figure2), which according to several authors is the PR value in which root growth is limited for most crops (Bengouch \& Mullins, 1990; Keller et al., 2014; Silva et al. 2015; Peixoto et al., 2019). This is an indicative of the management used to cultivated coffee crop was adequate to soil structure quality maintaining some environmental sustainability.

It is important to note that the similarities between the soils, in the row position, were probably due to the reorganization of the natural structure when the furrows were opened, with a possible further stabilization of this structure. This stability may have been favored by the gypsum dose $\left(7 \mathrm{~kg} \mathrm{~m}^{-1}\right.$ added on the soil surface in the planting row), which provided additional exchangeable $\mathrm{Ca}^{2+}$ of $40 \mathrm{mmol}_{\mathrm{c}} \mathrm{dm}^{-3}$, associated to organic carbon storage (56 Mg ha-1 at $0.15 \mathrm{~m}$ depth) supplied by coffee residues, Brachiaria and their roots system (Silva et al., 2013; Carducci et al., 2015).

The synergism of those factors have been responsible for the mineral particles flocculation and increased biological activity, which contribute to the formation of new voids and consequently soil compaction relief (Carducci et al., 2013; An et al., 2015; Liu et al.,
2017; Flávio Neto et al., 2015; Bonetti et al., 2017), as confirmed by high MA, low RP and $\mathrm{BD}$ values for the kaolinitic Oxisol $(\mathrm{KH})$ (Figure 1 and 2).

We could observe that in the planting row, regardless of the depth analyzed, both Oxisols had a lower strength in relation to the interrow position $\left(\sigma_{\mathrm{p}}: \leq 500 \mathrm{kPa} ; \Psi \mathrm{m}\right.$ : $3000 \mathrm{kPa}$ $=\theta \pm 0,20 \mathrm{~cm}^{3} \mathrm{~cm}^{-3}$ ) as represented in the preconsolidation stress model $\left(\sigma_{\mathrm{p}} \times \Psi_{\mathrm{m}}\right)$ (Figure 3). Thus, it can be stated these Oxisols under the same multi-practice conservationist soil management after 3.5-yrs old of cultivation, presented a more homogenous structure, and increase porosity (Figure 1) even with striking mineralogical distinction (Severiano et al., 2013; Iori et al., 2013; Carducci et al., 2014; Andrade et al., 2017).

Possible changes that occurred in these Oxisols due to the used of soil multipractice management may be related for the synergisms of additional gypsum, roots action of the tropical forage and their residues, small soil terrace on the plantation row, and soil inputs for fertility purposes. This entire factors joint promoted biological activity and particle flocculation, due to increased exchangeable $\mathrm{Ca}^{2+}$ and humic substances (Silva et al., 2013; Zinn et al., 2007; Flávio Neto et al., 2015). As a result, new homogeneous aggregates are formed after the intense mixing during the initial soil preparation phase. Additionally, intermediate ratios of gibbsite [Gb/(Gb+Kt)] may have translated into some resilience to external pressure, especially under friable soil conditions (Bengouch \& Mullins, 1990; Ajayi et al., 2009b; Severiano et al., 2013; An et al., 2015; Carducci et al., 2014; Bonetti et al., 2017; Mazurana et al., 2017). 
The explanation for the higher strength of GA at lower $\Psi_{m}$ could be seen in the Figureure 2 , where the rapid loss of water can be seen in GA (slope) typically of this weathered Oxisol (Table 1) indicates variety of large pores diameter (Dexter \& Richard, 2009; Reynolds et al., 2009; Carducci et al., 2013; Carducci et al., 2014), suggesting faster water drainage and consequently, a quick soil drying in relation to the $\mathrm{KH}$ at the same $\Psi_{\mathrm{m}}$ range, in according to preconsolidation stress model.

It is known that soil water content is the main parameter responsible for the lubrication of the mineral particles corresponding to greater or lesser soil deformation (Severiano et al., 2013; An et al., 2015; Shahgholi \& Abuali, 2015). Although machine traffic usually occurs at harvest season (July to September), when $\Psi_{m}$ in the Oxisols studied is higher $\left(\Psi_{m}>\right.$ $1500 \mathrm{kPa}$ ). Thus, decreasing the compaction risk, one must take into account that $\sigma_{p}$ is the highest pressure that should be applied to the soil in order to prevent additional compaction (Dias Júnior \& Pierce, 1995; Severiano et al., 2013; Silva et al., 2016b; Guimarães Júnnyor et al., 2019).

The pressure values applied to the soil by agricultural machinery, reported in the literature, range from 50 to $650 \mathrm{kPa}$ (Horn et al., 2007; Keller et al., 2014; Eliasson, 2005), however it is advisable to take cautionary measures to favor machine and/or animal traffic when low soil water contents are present. In this way, by decreasing the water content the soil resistance would be optimal as a result of the cohesion between soil particles, reducing their susceptibility to displacement and rearrangement processes (An et al., 2015, Pirnazarov \& Sellgren, 2015; Guimarães Júnnyor et al., 2019).

\section{Conclusions}

Superior physical quality of both Oxisols was observed especially in the planting row position (decreased mechanical resistance and increased porosity), although mineralogical distinct, they were similar behavior about physical properties. Overall, the findings herein are in accordance with global trends towards conservationist management systems that may alleviate soil compaction in agriculture to contribute with the maintaining of environmental sustainability. The use of all conservationist multi-practices associated with greater gibbsite content can promoted changes in soil structure, which resulted in more resilient soils (on the interrow) improving resistance to external pressures applied in the gibbsitic Acrustox.

The use of linear mixed regression theory proved to be a useful statistical tool to estimate the susceptibility to soil compaction of weathering Oxisols under same management system with variation in the mineralogical composition. In this way, the preconsolidation stress was accurate in detecting the superiority of strength in GA (gibbsitic Acrustox) in the interrow position, because this theory was able to take into account features such as soil taxon, sampling position, depth and matric tension, as well as their interactions, at the same time.

\section{Acknowledgments}

To CNPq, FAPEMIG, CAPES and Embrapa Café for the financial support to carry out this work; to UFLA for institutional support; and to AP farm - Agropecuária Piumhi for releasing sampling areas and for the logistical support. 


\section{Conflicts of interest}

The authors declare no conflicts of interest.

\section{References}

Ajayi, A. E., Dias, M. S., Jr., Curi, N., Araujo, C. F., Jr., Souzam, T. T. T., \& Inda, A. V., Jr. (2009a). Strength attributes and compaction susceptibility of Brazilian Latosols. Soil \& Tillage Research, 105(1), 122-127. doi: 10.1016/j.still.2009.06.004

Ajayi, A. E., Dias, M. S., Jr., Curi, N., Gontijo, I., Araújo, C. F., Jr., \& Vasconcelos, A. I., Jr. (2009b). Relation of strength and mineralogical attributes in Brazilian Latosols. Soil \& Tillage Research, 102(1), 14-18. doi: 10.1016/j.still.2008.05.013

Ajayi, A. E., Dias, M. S., Jr., Curi, N., Okunola, A., Souza, T. T. T., \& Pires, B. S. (2010). Assessment of vulnerability of Oxisols to compaction in the Cerrado region of Brazil. Pedosphere, 20(2), 252-260. doi: 10.1016/ S1002-0160(10)60013-6

Alvares, C. A., Stape, J. L., Sentelhas, P. C., Gonçalvez, J. L. M., \& Sparovek, G. (2014). Köppen's climate classification map for Brazil. Meteorologische Zeitschrift, 22(6), 711-728. doi: 10.1127/0941-2948/2013/ 0507

An, J., Zhang, Y., \& Yu, N. (2015). Quantifying the effect of soil physical properties on the compressive characteristics of two arable soils using uniaxial compression tests. Soil \& Tillage Research, 145(1), 216-223. doi: 10.1016/j.still.2014.09.002
Andrade, M. L. C., Tassinari, D., Dias, M. S., Jr., Martins, R. P., Rocha, W. W., \& Souza, Z. R. (2017). Soil compaction caused by harvest and logging operations in eucalyptus forests in coarse-textured soils from northeastern Brazil. Ciência e Agrotecnologia, 41(2), 191-200. doi: 10.1590/1413-70542017412036216

Barbosa, S. M., Silva, B. M., Oliveira, G. C., Benevenute, P. A. N., Silva, R. F., Curi, N.,... Pereira, V. M. (2020). Deep furrow and additional liming for coffee cultivation under first year in a naturally dense Inceptisol. Geoderma, 357(1), 113934. doi: 10.1016/j.geoderma.2019.113934

Bengouch, A. G., \& Mullins, C. E. (1990). Mechanical impedance to root growth: a review of experimental techniques and root growth responses. European Journal of Soil Science, 41(3), 341-358. doi: 10.1111/j. 1365-2389.1990.tb00070.x

Bernardes, T., Moreira, M. A., Adami, M., Giarolla, A., \& Rudorff, B. F. T. (2012). Monitoring biennial bearing effect on coffee yield using MODIS Remote Sensing Imagery. Remote Sensing, 4, 2492-2509. doi: 10.1109/IGARSS.2012.6350499

Blake, G. R., \& Hartge, K. H. (1986). Partycle density. In A. Klute (Ed.), Methods of soil analysis (2nd ed.), American Society of Agronomy, Agronomy Monographs 9(1). Methods of soil analysis, Madison, Wisconsin (pp. 377-382).

Bonetti, J. A., Anghinoni, I., Moraes, M. T., \& Fink, J. R. (2017). Resilience of soils with different texture, mineralogy and organic matter under long-term conservation systems. Soil \& Tillage Research, 174, 104-112. doi: 10.1016/j.still.2017.06.008 
Carducci, C. E., Oliveira, G. C., Curi, N., Heck, R. J., \& Rossoni, D. F. (2014). Scaling of pores in 3D images of Latosols (Oxisols) with contrasting mineralogy under a conservation management system. Soil Research, 52(3), 231-243. doi: 10.1071/ SR13238

Carducci, C. E., Oliveira, G. C., Curi, N., Heck, R. J., Rossoni, D. F., Carvalho, T. S. de, \& Costa, A. L. (2015). Gypsum effects on the spatial distribution of coffee roots and the pores system in oxidic Brazilian Latosol. Soil \& Tillage Research, 145(1), 171-180. doi: 10.1016/j.still.2014.09.015

Carducci, C. E., Oliveira, G. C., Zeviani, W. M., Lima, V. M. P., \& Serafim, M. E. (2013). Bimodal pore distribution on soils under conservation management system for coffee crop. Engenharia Agrícola, 33(2), 291-302. doi: 10.1590/S010069162013000200008

Companhia Nacional de Abastecimento (2020). Acompanhamento da safra brasileira Café safra 2020, primeiro levantamento. Recuperado de https://www.conab.gov.br/ info-agro/safras/cafe

Danielson, R. E., \& Sutherland, P. L. (1986). Porosity. Methods of soil analysis: Part 1 physical and mineralogical methods, (2nd ed.). In: A. Klute (Ed.), American Society of Agronomy, Agronomy Monographs 9(1). Methods of soil analysis, Madison, Wisconsin (pp.443-461).

Day, P. R. (1965). Particle fractionation and particle size analysis. In: C. A. Black, D. D. Evans, L. E. Ensminger, J. L. White, F. E. Clark (Eds.), Methods of soil analysis. Madison, Wisconsin (pp. 545-567).
Dexter, A. R., \& Richard, G. (2009). Tillage of soils in relation to their bi-modal pore size distributions. Soil \& Tillage Research, 103(1), 113-118. doi: 10.1016/j. still.2008.10.001

Dias, M. S., Jr., \& Pierce, F. J. (1995). A simple procedure for estimating preconsolidation pressure from soil compression curves. Soil Technology, 8(2), 139-151. doi: 10.10 16/0933-3630(95)00015-8

Eliasson, L. (2005). Effects of forwarder tyre pressure on rut formation and soil compaction. Silva Fennica, 39(4), 549557. doi: $10.14214 /$ sf.366

Ferreira, C. J. B., Tormena, C. A., Severiano, E. C., Zotarelli, L., \& Bertiolo, E., Jr. (2020). Soil compaction influences soil physical quality and soybean yield under longterm no-tillage. Archives of Agronomy and Soil Science, 1(1), 1-14. doi: 10.10 80/03650340.2020.1733535

Flávio, J., Neto, Severiano, E. C., Costa, K. A. P., Guimarães Junnyor, W. S., Gonçalves, W. G., \& Andrade, R. (2015). Biological soil loosening by grasses from genus Brachiaria in croplivestock integration. Acta Scientiarum: Agronomy, 37(3), 375-383. doi: 10.4025/actasciagron.v37i3.19392

Genuchten, M. T. (1980). Aclosed-formequation for predicting the hydraulic conductivity of unsaturated soils. Soil Science Society of American Journal, 44(5), 892-898. doi: $\quad 10.2136 /$ sssaj1980.036159950044 $00050002 x$

Götze, P., Rücknagel, J., Jacobsm, A., Märländer, B., Kohn, H. J., \& Christen, O. (2016). Environmental impacts of different crop rotations in terms of soil compaction. Journal of Environmental 
Management, 181(1), 54-63. doi:10.1016/j. jenvman.2016.05.048

Guimarães Júnnyor, W. S., Diserens, E., Maria, I. C. de, Araujo, C. F., Jr., Farhate, C. V. V., \& Souza, Z. M. (2019). Prediction of soil stresses and compaction due to agricultural machines in sugarcane cultivation systems with and without crop rotation. Science of Total Environmental, 681(3), 424-434. doi: 10.1016/j.scitotenv. 2019.05.009

Horn, R., Vossbrink, J., Peth, S., \& Becker, S. (2007). Impact of modern forest vehicles on soil physical properties. Forest Ecology and Management, 248(1-2), 56-63. doi: 10.1016/j.foreco.2007.02.037

Iori, P., Dias, M. S., Jr., Ajayi, A. E., Guimarães, P. T. G., Pais, P. S. M., \& Andrade, M. L. C. (2013). Comparison of field and laboratory models of the load bearing capacity in coffee plantations. Ciência e Agrotecnologia, 37(2), 130-137. doi: 10.1590/S1413-7054 2013000200003

IUSS Working Group WRB (2014). World reference base for soil resources 2014 (2nd ed.). (World Soil Resources Report, $\mathrm{n}$. 106. F.). Rome: FAO.

Keller, T., Berli, M., Ruiz, S., Lamandé, M., Arvidsson, J., Schjønning, P., \& Selvadurai, A. P. S. (2014). Transmission of vertical soil stress under agricultural tyres: comparing measurements with simulations. Soil \& Tillage Research, 140(7), 106-117. doi: 10.1016/j.still.2014.03.001

Laird, N. M., \& Ware, J. H. (1982). Random-effects models for longitudinal data. Biometrics, 38(4), 963-974. doi: 10.2307/2529876

Liu, Q., Liu, B., Zhang, Y., Lin, Z., Zhu, T., Sun, R.,... Xie, Z. (2017). Can biochar alleviate soil compaction stress on wheat growth and mitigate soil $\mathrm{N}_{2} \mathrm{O}$ emissions? Soil Biology and Biochemistry, 104(1), 8-17. doi: 10. 1016/j.soilbio.2016.10.006

Mazurana, M., Levien, R., Inda, A. V., Jr., Conte, O., Bressani, L. A., \& Müller, J. (2017). Soil susceptibility to compaction under use conditions in southern Brazil. Ciência e Agrotecnologia, 41(1), 60-71. doi: 10. 1590/1413-70542017411027216

Pedrotti, A., Ferreira, M. M., Curi, N., Silva, M. L. N., Lima, J. M., \& Carvalho, R. (2003). Relação entre atributos físicos, mineralogia da fração argila e formas de alumínio no solo. Revista Brasileira de Ciência do Solo, 27(1), 1-9. doi: 10.1590/ S0100-06832003000100001

Peixoto, D. S., Silva, B. M., Oliveira, G. C., Moreira, S. G., Silva, F., \& Curi, N. (2019). A soil compaction diagnosis method for occasional tillage recommendation under continuous no tillage system in Brazil. Soil \& Tillage Research, 194(11), 104307. doi: 10.1016/j.still.2019.104307

Pirnazarov, A., \& Sellgren, U. (2015). Reduced testing and modelling of the bearing capacity of rooted soil for wheeled forestry machines. Journal of Terramechanics, 60(1), 23-31. doi: 10. 1016/j.jterra.2015.05.002

$\mathrm{R}$ Core Team (2019). R: A language and environment for statistical computing. Vienna, Austria: RFoundation for Statistical Computing. Retrieved from http://www.Rproject.org/

Resende, M., Bahia, A. F. C., Fo., \& Braga, J. M. (1987). Clay mineralogy of Latosols estimated by chemical allocation of total oxides contente by $\mathrm{H}_{2} \mathrm{SO}_{4}$ digestion. 
Revista Brasileira de Ciência do Solo, 11(1), 17-23.

Reynolds, W. D., Drury, C. F., Tan, C. S., Fox, C. A., \& Yang, X. M. (2009). Use of indicators and pore volume-function characteristics to quantify soil physical quality. Geoderma, 152(3-4), 252-63. doi: 10. 1016/j. geoderma.2009.06.009

Santos, H. G., Jacomine, P. K. T., Anjos, L. H. C., Oliveira, V. A., Lumbreras, J. F., Coelho, M. R.,... Cunha, T. J. F. (2018). Brazilian soil classification (5nd ed. rev. and exp.). Brasília, DF: EMBRAPA.

Santos, W. J.R., Silva, B.M., Oliveira, G. C., Volpato, M. M. L., Lima, J. M., Curi, N., \& Marques, J. J. (2014). Soil moisture in the root zone and its relation to plant vigor assessed by remote sensing at management scale. Geoderma, 221-222(6), 91-95. doi: 10.1016/j.geoderma.2014.01.006

Severiano, E. C., Oliveira, G. C., Dias, M. S., Jr., Curi, N., Costa, K. A. P., \& Carducci, C. E. (2013). Preconsolidation pressure, soil water retention characteristics, and texture of Latosols in the Brazilian Cerrado. Australian Soil Research, 51(3), 193-202. doi: 10.1071/SR12366

Shahgholi, G., \& Abuali, M. (2015). Measuring soil compaction and soil behavior under the tractor tire using strain transducer. Journal of Terramechanics, 59(1), 19-25. doi: 10.1016/j.jterra.2015.02.007

Silva, B. M., Oliveira, G. C., Serafim, M. E., Silva, E. A., Ferreira, M. M., Norton, L. D., \& Curi, N. (2015). Critical soil moisture range for a coffee crop in an oxidic latosol as affected by soil management. Soil \& Tillage Research, 154(1), 103-113. doi: 10.1016/j. still.2015.06.013
Silva, B. M., Oliveira, G. C., Serafim, M. E., Silva, E. A., Guimarães, P. T. G., Melo, L. B. B.,... \& Curi, N. (2019). Soil moisture associated with least limiting water range, leaf water potential, initial growth and yield of coffee as affected by soil management system. Soil \& Tillage Research, 189(1), 36-43. doi: 10. 1016/j.still.2018.12.016

Silva, E. A., Oliveira, G. C., Carducci, C. E., Silva, B. M., Oliveira, L. M., \& Costa, J. C. (2013). Increasing doses of agricultural gypsum, aggregate stability and organic carbon in Cerrado Oxisol under Coffee crop. Revista Ciências Agrárias-Amazonian Journal of Agricultural and Environmental Sciences, 56(1), 25-32. doi: 10.4322/rca.2013.012

Silva, E. A., Silva, S. H. G., Oliveira, G. C., \& Carducci, C. E. (2016b). Root spatial distribution in coffee plants of different ages under conservation management system. African Journal of Agriculture Research, 11(49), 4970-4978. doi: 10. 5897/AJAR2016.11356

Silva, R. B., lori, P., Souza, Z. M., Pereira, D. M. G., Vischi, O. J., Fo., \& Silva, F. A. M. (2016a). Contact pressures and the impact of farm equipment on Latosol with the presence and absence of sugarcane straw. Ciência e Agrotecnologia, 40(3), 265-278. doi: 10.1590/1413-70542016403001716

Skorupa, A. L. A., Tassinari, D., Silva, S. H. G., Poggere, G. C., Zinn, Y. L., \& Curi, N. (2016). Xanthic- and Rhodic-Acrudoxes under cerrado vegetation: differential internal drainage and covarying micromorphological properties. Ciência e Agrotecnologia, 40(4), 443-453. doi: 10.1590/1413-70542016404019916 
Soil Survey Staff (2014). Keys to soil taxonomy (12nd ed.). Washington, DC: USDA-Natural Resources Conservation Service.

Taylor, D. W. (1948). Fundamentals of soil mechanics. New York: John Wiley \& Sons.

Teixeira, P. C., Donagemma, G. K., Fontana, A., \& Teixeira, W. G. (2017). Manual de métodos de análise de solo (3nd ed. rev. and ampl.). Brasília, DF: EMBRAPA. Tollefson, J. (2010). Food: the global farm. Nature, 466(29), 554-556. doi: 10.1038/466554a
Vollant-Tuduri, N., Bruand, A., Brossard, M., Balbino, L. C., Oliveira, M. I. L., \& Martins, É. S. (2005). Mass proportion of microaggregates and bulk density in a Brazilian clayey Oxisol. Soil Science Society of American Journal, 69(5), 15591564. doi: $10.2136 /$ sssaj2003.0344

Zinn, Y. L., Lal, R., Bigham, J. M., \& Resck, D. V. S. (2007). Edaphic controls on soil organic carbon retention in the Brazilian Cerrado: texture and mineralogy. Soil Science Society of American Journal, 71(4), 12041214. doi: $10.2136 /$ sssaj2006.0014 
